\title{
Food efficiency of rats maintained on a diet with varied casein : gluten
}

\author{
Omar Obeid and Melanie Mattar \\ American University of Beirut, Beirut, Lebanon
}

The increasing prevalence of CVD and its association with animal-protein intake in many societies has stimulated the adoption of plantbased dietary regimens such as vegetarianism ${ }^{(1)}$. The contribution of plant proteins to the total protein intake represents $100 \%$ in vegans, $66.4 \%$ in vegetarians and $41 \%$ in omnivores ${ }^{(2)}$, of which cereals, especially wheat, are the major sources. In addition, the consumption of cereals and their products is known to contribute to a considerable proportion of the protein and energy intake in most developing societies ${ }^{(3)}$. Wheat, however, is categorized as a low-quality protein source since its constituent protein, gluten, is limited in the essential amino acid lysine. It is well known that rats maintained on a diet in which gluten is the only source of protein would suffer from growth impairment ${ }^{(4)}$. However, it is not clear whether increased gluten contribution to the diet would affect food efficiency (weight gain ( $g$ ) per $100 \mathrm{~g}$ food intake).

The present study was designed to investigate the effect of altering the protein quality of an isonitrogenous and isoenergetic diet on food efficiency of rats, which was achieved by varying the casein:gluten $(\mathrm{C}: \mathrm{G})$ of the diet. Forty-two adult male Sprague-Dawley rats were randomly divided into five groups based on the casein and gluten content of the diet, which constituted the only protein sources and contributed $20 \%$ dietary energy. The percentage contribution of gluten and casein to energy of the different diets were as follows: C20:G0, C15:G5, C10:G10, C5:G15, C0:G20. Food intake and body weight were monitored every 2 d for a period of 6 weeks.

\begin{tabular}{|c|c|c|c|c|c|c|c|c|c|c|c|}
\hline & \multicolumn{2}{|c|}{ C20:G0 } & \multicolumn{2}{|c|}{ C15:G5 } & \multicolumn{2}{|c|}{ C10:G10 } & \multicolumn{2}{|c|}{ C5:G15 } & \multicolumn{2}{|c|}{ C0:G20 } & \multirow[b]{2}{*}{$P$ (ANOVA) } \\
\hline & Mean & SE & Mean & SE & Mean & SE & Mean & SE & Mean & SE & \\
\hline Food intake (g/d) & $23.1^{\mathrm{a}}$ & 0.81 & $22.8^{\mathrm{a}}$ & 0.82 & $22.0^{\mathrm{a}, \mathrm{b}}$ & 0.89 & $20.4^{\mathrm{b}}$ & 0.63 & $19.7^{\mathrm{b}}$ & 0.71 & 0.012 \\
\hline $\begin{array}{l}\text { Food intake } \\
\qquad(\mathrm{g} / 100 \mathrm{~g} \text { body } \mathrm{wt})\end{array}$ & $7.17^{\mathrm{a}}$ & 0.09 & $7.13^{\mathrm{a}}$ & 0.12 & $6.92^{\mathrm{a}}$ & 0.12 & $6.77^{\mathrm{a}}$ & 0.14 & $7.68^{b}$ & 0.19 & 0.001 \\
\hline Wt gain $(\mathrm{g} / \mathrm{d})$ & $6.12^{\mathrm{a}}$ & 0.29 & $6.20^{\mathrm{a}}$ & 0.30 & $5.69^{\mathrm{a}, \mathrm{b}}$ & 0.25 & $5.33^{\mathrm{b}}$ & 0.20 & $2.79^{\mathrm{c}}$ & 0.19 & 0.001 \\
\hline Food efficiency & $14.6^{\mathrm{a}}$ & 0.78 & $13.8^{\mathrm{a}, \mathrm{b}}$ & 0.34 & $13.2^{\mathrm{a}, \mathrm{b}}$ & 0.19 & $12.9^{\mathrm{b}}$ & 0.44 & $6.31^{\mathrm{c}}$ & 0.46 & 0.001 \\
\hline
\end{tabular}

$\overline{\mathrm{a}, \mathrm{b}, \mathrm{c}}$ Mean values in the same row with unlike superscript letters were significantly different (Fisher's post-hoc test; $P<0.05$ ).

Results showed that the average food intake of the high-gluten groups (C0:G20 and C5:G15) was decreased by about 10\% in comparison with the other groups; however, when food intake was expressed per $100 \mathrm{~g}$ body weight only that of the gluten-only diet showed a modest increase. Average weight gain of the high-gluten groups (C0:G20 and C5:G15) decreased by about 50\% and 10\% respectively and this decrease was associated with a similar pattern in terms of the reduction in food efficiency.

In conclusion, increasing the contribution of gluten to the diets is associated with a decrease in food efficiency mainly as a result of a decrease in weight gain rather than a decrease in food intake. These effects are highly pronounced in the gluten-only group.

1. Hu FB (2003) Am J Clin Nutr 78, 544S-551S

2. Millward DJ (1999) Proc Nutr Soc 58, 249-260.

3. Millward DJ \& Jackson AA (2003) Public Health Nutr 7, 387-405.

4. Munaver SM \& Harper AE (1959) J Nutr 69, 58-64. 